\title{
Women's Empowerment and Gender Equality in Urban Areas: New Threats and Potentials in Nigeria
}

\author{
Stephen Sunday OJO ${ }^{1}$, Martina Alexander POJWAN ${ }^{2}$ \\ ${ }^{1}$ Department of Sociology, Federal University, Gashua Yobe State Nigeria \\ ${ }^{2}$ Department of Social Development, Isa Mustapha Agwai I Polytechnic, Lafia Nasarawa State Nigeria
}

\begin{abstract}
Urban settings currently provide the main arena for shaping gender relations. The process of urbanization provides both advantages and disadvantages for gender equality and the empowerment of women. In turn, gender relations are often critical in shaping the urbanization process itself, affecting decisions as to who migrates to cities, as well as how the household unit, family roles and local community organizations will be structured in the urban context. Urban conditions are frequently more difficult for women and children, especially among the poor, exposing them to new forms of exploitation and discrimination, in addition to greater environmental risks. Urban settings can, however, also present new opportunities for gender equality. This paper addresses some of these contradictory trends with respect to several interrelated issues and concludes that a gender-sensitive approach to urban governance would increase women's participation in the development of human settlements and improve the performance of cities in taking advantage of the urban potentials for social improvement.
\end{abstract}

Keywords: women empowerment, gender equality, urban areas, threats, potentials

\section{INTRODUCTION}

$\mathrm{C}$ urrently, the numbers of urban and rural dwellers in the world are almost evenly split, with slightly more concentrating in urban areas. However, the share of urban dwellers is expected to rise to $70 \%$ by 2050 (UN-Habitat, 2009). Almost all of this growth will take place in developing countries. Cities are often engines of economic growth and social advancement, but rapid urbanization in most of the developing world has also resulted in stark inequalities between the rich and the poor, women and men, environmental degradations and growing numbers of slum dwellers. While urbanization offers many benefits, the ugly face of urbanization is urban poverty, which often has the most severe impact on women and girls. The world's 828 million slum dwellers suffer in varying degrees from poor sanitation, inadequate access to clean water, crime, unemployment, threats of evictions, overcrowding and poor quality housing. Women in cities often suffer disproportionately, not only because they are, on average, poorer than men but often also because they experience greater difficulty in accessing resources and services tailored to their needs, and decision-making opportunities.

Urban settings currently provide the main arena for shaping gender relations. The process of urbanization provides both advantages and disadvantages for gender equality and the empowerment of women. In turn, gender relations are often critical in shaping the urbanization process itself, affecting decisions as to who migrates to cities, as well as how the household unit, family roles and local community organizations will be structured in the urban context. Urban conditions are frequently more difficult for women and children, especially among the poor, exposing them to new forms of exploitation and discrimination, in addition to greater environmental risks. Urban settings can, however, also present new opportunities for gender equality, allowing women to escape from the traditional forms of discrimination that prevail in rural areas, encouraging work outside the home, and facilitating access to education, income and health services, as well as participation in public and political life. This paper addresses some of these contradictory trends with respect to several interrelated issues: working outside the home, living conditions, family formation and social participation.

\section{WOMEN IN URBAN LABOUR MARKETS}

There is great deal of literature showing the importance of women in the area of employment, particularly their involvement in the labour force. From time immemorial, women are known to have been actively involved in the provision of labour needed for economic growth. However, lack of available and reliable data has made it difficult for women to be assessed and their labour quantified to establish the amount they put into the development process.

Working for income outside the home is a key facet of women's empowerment. Paid employment for women can elevate their status and favour transformations in gender roles. Urbanization has undoubtedly presented new opportunities for women in terms of access to employment and income, although this access is still gender-differentiated. Two broad trends prevail: the feminization of the labour force and the informalization of the labour market.

Despite their increasing numbers, women have tended to enter the workforce in lower status, lower-paying jobs and remain clustered in a limited number of conventional careers. Lowpaying traditionally female careers, including administrative support; sales, service, nursing, teaching, social work, and clerical jobs, reflected society's persistent attitudes regarding stereotypical gender occupational roles.

There has been a huge increase in female labour-force participation in non-agricultural wage employment (UNRISD, 
2005). This rise is partly due to a growing demand for female labour force in industrial activities and partly to changing household survival strategies brought on by urbanization itself. Trade liberalization has created employment opportunities for women. Nevertheless, these opportunities can disappear quickly, as business ventures move from country to country or as labour demands change. Moreover, the same factors that led to women's inclusion in the global economy in the first place - unskilled work, low wages and low productivity - can also exclude them (Avirgan, 2005). Women remain segregated and concentrated at the margins of the production process and at the lower end of the commodity chain in these female-intensive subsectors. Wages are low, contracts are rarely formalised and social benefits (health insurance, vacations, and maternity or sick leave) are rare.

\section{Women in the urban informal economy}

The deregulation and informalization of the labour market that accompanied economic restructuring in the developing world has led to an increase in working at home. Women are now a large majority in informal and non-standard employment, especially among own-account workers in non-agricultural employment.

The contribution of the informal sector to GDP is being increasingly recognized; estimates indicate that it represents 29 per cent of GDP in Latin America and 41 per cent in Asia (ILO, 2002). It comprises half to three-quarters of nonagricultural employment in developing countries and constitutes a larger source of employment for women that for men; over 60 per cent of female non-agricultural workers in developing world are in this sector (ILO, 2002). In subSaharan Africa, 84 per cent of women non-agricultural workers are informally employed compared to 63 per cent for men.

Increasing feminization of labour in urban areas has accompanied an informalization of labour, but informal sector activities (e.g. street vending) are precarious, mostly unregistered, poorly paid, typically lacking contracts and social protection (Tacoli, 2012). Also, employment in the informal sector can be either a boon or a drawback for women. While it does offer positive opportunities, such as flexibility of work hours and the convenience of working from home, informal employment often does not provide adequate working conditions. A cursory look at street vendors in Nigeria indicates that the income of women was lower than that of men, that women often suffered harassment and that they were deprived of certain privileges. Several have been subjected to sexual abuse, as exchange for selling their products.

\section{WOMEN'S ACCESS TO HOUSING AND BASIC SOCIAL SERVICES}

Access to secure and safe housing is critical for exploiting what the city has to offer, especially for women. Yet, according to UN-Habitat (2006), close to a billion people today live in substandard housing. Moreover, it is generally acknowledged that women's priorities tend to be ignored in the design of human settlements, the location of housing and the provision of urban services. Urban planning has been more concerned with issues that are defined in physical and spatial terms and that are linked to men's work patterns without considering the needs and priorities of women.

In addition to suffering the effects of overcrowding, inadequate infrastructure and services, and insecurity of tenure, women and children bear the health burdens of water, sanitation, hygiene and related inadequacies, the most serious of which tend to be concentrated in and around people's homes. The labour burden of these inadequacies falls especially hard on women living in poverty.

These conditions should not, however, overshadow the fact that urban women generally benefit from better infrastructure than those living in rural areas. For instance, urban households are more likely to have flush toilets or piped water either in or near the home. They are also much more likely to have access to public transport and to live near a health centre. However, access to, as well as use of and control over, urban infrastructure facilities and social services is different for men and women: such disparities are linked to inequalities in household relations, property rights and cultural restrictions. Women tend to be disadvantaged as a result of socio-cultural factors and gender discrimination in urban services. For instance, women are often subject to greater risks in public toilets or showers.

\section{Access to public transport}

Mobility is one of the main conditions for social and economic insertion in urban environments, but the relations between gender and transport go unrecognized in city planning (Peters, 2001). Women's travel needs are at least as great as those of men, though often radically different. Both economic and social considerations determine women's choices in modes of transport. The findings of a study in five different developing-country cities indicate that (a) more women than men have no mode of transport available and are thus forced to walk; (b) more women than men depend on public transport; (c) women are less likely than men to have access to motorized means of transport; and (d) women are less likely than men to have access to bicycles or other intermediate means of transport (Peters, 2001).

Women do not benefit equally to men in urban environments. Gender inequalities are experienced in many areas of everyday life, accessing decent work opportunities, increased workloads with the double-burden of earning income and casework, accessing financial assets and housing security, access to services, engaging in public governance structures, and personal security, the latter due in part to unfavourable infrastructure and transport designs (Chant \& Mellwaine, 2016; Moser, 2016; Tacoli \& Satterthwait, 2013). 
Even when available, public transport is often inadequate; this has various effects on women, including isolation, physical wear and stress, and health costs. Where bus frequencies are reduced, the ability of elderly women to reach basic services or to visit relatives is also reduced. Similarly, women's comparatively restricted mobility hinders them in gaining access to health knowledge and health services (OECD, 2004). Gender-responsive infrastructure interventions can free up women's time, thereby increasing the enrolment of girls in school and facilitating women's participation in incomegenerating and decision-making activities.

\section{Access to childcare services}

High rates of urbanization and increasing levels of female participation in the labour force increase the demand for nonparental childcare in cities of developing countries (UNFPA and GTZ, 2007). Holding a job and caring for one's children are often separate activities that compete for a mother's time, especially when distances are great and transportation facilities are inadequate. Moreover, rural-to-urban migration often entails moving from one's extended family, a traditional source of informal childcare.

In short, greater options for women's work often occur in settings that are not compatible with the care of children and other dependents. The decision to participate in the labour market is often influenced by the availability of childcare. The lack of childcare facilities is especially crucial for women without a spouse, who often have to choose informal sector jobs due to greater flexibility. Reliable and affordable childcare alternatives are thus becoming increasingly important in urban areas.

Women's career are hampered by the lack of high-quality childcare provision, which is necessary to give parents, especially mothers, a genuine choice as to how much paid work they undertake. Women continue to have most of the responsibility for childcare and domestic work. This needs to change and men need to be encouraged to become more involved in areas of paid and unpaid childcare, which has traditionally been the responsibility of women.

Indeed, employers express a preference for young women in factory jobs, banking industries and often terminate employment once a worker gets married or becomes pregnant. Although women in urban settings are getting more involved in paid and unpaid work, this does not reflect in equal distribution of domestic responsibilities and being supported by men in care work (Chant, 2013; Evans, 2015). Time deficit women faces as a result of dual responsibilities of earning income and care responsibilities reduces their ability to pursue other opportunities offered in urban centres (Reichlin \& Shaw, 2015).

\section{FAMILY, FERTILITY AND GENDER TRANSFORMATIONS IN URBAN CONTEXTS}

Urban living makes the biggest difference in gender relations at the household level. The typologies and characteristics of families and households present important rural-urban differences. The shift from extended to nuclear families is more prevalent in urban areas and has paved the way for several new family forms. The increase in divorce, separation, cohabitation and remarriage rates in urban areas also places different strains on women's social and economic lives.

Research suggests that appropriate work and housing are critical prerequisites for family formation in urban contexts (Mulder and Wagner, 2001). Many people may thus need to delay childbearing in large cities and some may eventually have a smaller family than initially planned, or no family at all (Kulu, 2013). While economic considerations may be one factor behind small family size in big city environments, it is equally likely that the phenomenon is one expression of one modern individualistic urban society, which are supported by increased female labour force participation and promoted by continued gender inequality within families in many urban cities (McDonald, 2000).

\section{Family, fertility and gender identities}

Urbanization is considered one of the major social changes associated with the fertility transition in classic demographic theory (Mason, 1997). However, in developing countries, this has been overshadowed by widely shared assumptions that rapid urban growth is a negative phenomenon (Mabogunje, 2007). In spite of this perception, urban areas are universally acknowledged to provide powerful incentives, as well as lifestyle constraints, that can serve to change the fertility regime, resulting in lower fertility rates (UNFPA and PRB, 2005; McNicoll, 2006).

Higher levels of education, wage work and other opportunities for women associated with urban living are among the mechanisms underlying lower urban fertility. Women in urban areas are also more exposed to modern values that encourage control of their own reproduction and later marriage, and they are less under the influence of kin who control the timing of marriage and choice of spouse. Young women and men living in urban contexts in the developing world are thus much less likely to marry early (Mensch, 2005).

Urbanization also increases access to education and life options for girls and women. In Nigeria, for example, primary school completion among urban women is more than double that of rural women. However, urban residence appears to benefit young people in the upper two income categories more than the extremely poor.

\section{Violence against women}

Gender-based violence is a core area of focus in analysing women's economic empowerment, and in urban settings, more particularly, where gender norms may be challenged (Moser, 2016). Urban women are confronted with new forms of vulnerability and discrimination. Violence against women in urban areas is often closely linked to access to housing and shelter. Women subjected to domestic violence may remain in abusive relationships if they are unable to secure rights to land 
and property except through their husbands. In some contexts, violence between different urban groups is often played out by attacks on women, thereby restricting their access to public life and space.

Urban violence against women limits women's movement and their use of public space, especially among the most poor and marginalized (Taylor, 2011; Nesbitt-Ahmed, 2015). Violence in urban contexts is typically generated from urban poverty, political motives, targeted violence against women (sexualbased violence) or a combination of these factors. These motives may result in harassment and sexual violence against women, restricting women's movement, potentially curtailing women's economic, educational and social opportunities, exposing women to health and stress risks and creating severe infringements on women's rights to the city (Taylor, 2011).

Tacoli (2012), also reports that the relationship between women's paid employment and domestic abuse often depends on the type of work women and men may be involved in. women working in irregular, low paid and casual jobs are more likely to face domestic violence than those in better paid, higher quality jobs, because they have more resources and choices to resist. Violence against women is also found to be more likely when male partners are unemployed or have irregular work and when the household bears financial difficulties.

Transitional cultural contexts present particular problems. For instance, in urban centres in Nigeria, human rights organizations have documented numerous cases of in-laws exploiting women when their husbands die: relatives interfere with widows' access to pensions, death benefits, bank accounts and property (Human Rights Watch, 2003).

On the other hand, cities often develop more comprehensive policy responses to gender-based violence. Security, legal and health services for female victims of violence are much more likely to be available in urban areas. Several cities construct partnerships between women's organizations and the city administration to address safety issues for both women and men.

\section{Access to reproductive health services}

Urban areas can provide services and infrastructure at a much lower per capita cost due to their obvious advantages in terms of scale and proximity. Thus urban-rural differences in access to basic public health infrastructure are striking, even in poor countries, where many cities have managed to respond to basic public health needs. In Nigeria like other developing countries, for instance, government investments in the health sector tend to favour urban areas, while the provision of basic health services in rural areas is still lacking. Overall expenditures in social services declined in Nigeria under the structural adjustment programmes. Moreover, subsidies have been redirected away from rural areas towards urban industrial centres.
These overall urban advantages, however, are very unequally shared between poor and non-poor groups. The situation of poor urban populations is often akin to those of the rural poor. A study on the health of urban women and young children in developing countries found that household living standards have a substantial influence on two measures of women's health: unmet need for modern contraception and attendance of a trained provider at childbirth (Montgomery and Hewett, 2004). Taken together, these measures describe a relatively high-risk period in the lives of women.

\section{URBAN SETTINGS AND WOMEN'S ECONOMIC AND SOCIAL EMPOWERMENT}

Urban spaces provide many opportunities for women's interaction, association and participation in public life. The ability to join an association and participate in public life is an important resource for women's social, economic and political empowerment in urban settings. Modest neighbourhood groups started by women can be transformed into powerful national and international forces for social change.

In Nigeria, poor women in urban centres have also formed groups for economic purposes (so-called 'merry-go-rounds', 'adache' where members contribute money to lend to an individual) and to provide for their needs (purchases of household items and so on). Group members also assist each other for funerals, weddings and emergency fundraising.

In short, various experiences and initiatives are helping to find ways in which urban settings can become spaces for the redefinition of gender roles, and where women can find new ways and life choices through better access to association, public participation and decision-making.

\section{CONCLUSION}

Urbanization is a worldwide phenomenon especially now that developing countries of the world are increasingly being integrated into the global capitalist system. Unfortunately, the urban milieus have not been able to meet the challenges of urbanization

Urban conditions are frequently more difficult for women and children, especially among the poor, exposing them to new forms of exploitation and discrimination, in addition to greater environmental risks. Despite their obvious vulnerabilities, urban settings continue to provide opportunities for women empowerment, personal realization and gender equality.

\section{RECOMMENDATION}

The foregoing sections highlight both the potentialities and the limitations of urban life for gender equity. Much could be improved with greater attention to women's needs in urban planning, through small investments, and above all, with a greater reliance on women's and other neighbourhood organizations. Urban governance demands that issues of social equity and political legitimacy be increasingly incorporated to bolster administrative efficiency. 
Men and women experience and use the urban environment in different ways and have different priorities in terms of services and infrastructure. A gender-sensitive approach to urban governance would increase women's participation in the development of human settlements and improve the performance of cities in taking advantage of the urban potentials for social improvement.

\section{REFERENCES}

[1] Avirgan, T., Bivens, L.J. \& Gammage, S. (eds) (2005). Good jobs, Bad jobs, No jobs: Labour Market and Informal Works in Egypt, El Salvador, India, Russia and South Africa. Washington, DC. Economic Policy Institute, Global Policy Network.

[2] Chant, S. (2013). Cities through a "gender lens": a golden "urban age" for women in the global south? Environment and Urbanisation. Vol 25, 9-29.

[3] Chant, S. \& Mcllwaine C. (2013). Gender, urban development and the politics of space. E-International Relations - open access website. Retrieved from: http://www.e-ir.info/2013/06/04/genderurban-development-and-the-politics-of-space/.

[4] Evans, A. (2015). Egalitarian social change: current projects: (1) rural-urban differences in gender relations; (2) the decline of the male breadwinner but persistence of the female homemaker; (3) ideas, and why they matter for international development (Web blog post). Retrieved from: http://www.geog.cam.ac.uk/people/evans/.

[5] Human Rights Watch (2003). Double Standards: Women's Property Rights Violations, Human Rights Watch, vol 15, no 5(A), New York

[6] ILO (2002). Women and men in the informal economy: A statistical Picture, ILO, Geneva

[7] Kulu, H. (2013). Why do fertility levels vary between urban and rural areas? Regional Studies, vol 47, issue 6, 2013, pp 895-912

[8] Mabogunje, A.L. (2007). Global urban poverty research: The Africa case, Urban update, 10, Washington DC, Wilson International centre for scholars.

[9] McDonald, P. (2000). Gender equity in theories of fertility transition. Population and Development Review, vol 26, Issue 3, 2000, pp 427-439

[10] McNicoll, G. (2006). Policy lessons of the East Asian demographic transition, Policy Research Division Working Paper No 210, The Population Council, New York.

[11] Mensch, B.S. (2005). Trends in the timing of first marriage among men and women in the developing world, Policy Research Division Working Paper No 202, The Population Council, New York

[12] Montgomery, M.R. \& Hewett, P.C. (2004). Urban poverty and health in developing countries: Household and neighbourhood effects, Policy Research Division Working Paper No 184, The Population Council, New York

[13] Moser, C. (2016). Introduction: towards a nexus linking gender, assets and transformational pathways to just cities. In Moser, C. (Ed.) Gender, Asset Accumulation and just Cities: Pathways to transformation. (pp. 12-37). Abingdon, Oxon: Routledge.

[14] Mulder, C. \& Wagner, M. (2001). The connection between family formation and first time home ownership in the context of West Germany and Netherlands. European Journal of Population, vol 17, Issue 2, 2001, pp 137-164

[15] Nesbitt-Ahmed, Z. (2015). Structural Barriers to Inclusion: a focus on violence. Presentation given at IDS: From Urban Exclusion to Inclusive Urbanisation Workshop (October 29, 2015).

[16] OECD (2004). Why Gender Matters in Infrastructure, Development Assistance Committee, Network on Gender Equality, Organisation for Economic Co-operation and Development, Paris

[17] Peters, D, (2001). Gender and transport in LDCs: A background paper in preparation for CSD-9, Expert Workshop on Gender
Perspectives for Earth Summit 2002: Energy, Transport for Decision Making, Berlin, 10-12 January

[18] Reichlin, L. \& Shaw, E. (2015). Gender, Urbanisation and Democratic Governance. (White Paper written for the Institute for Women's Policy Research commissioned by the National Democratic Institute). Retrieved from: https://www.ndi.org/Gender-Urbanisation-and-DemocraticGovernance-white-paper

[19] Tacoli, C. (2012). Urbanisation, gender and urban poverty: paid and unpaid carework in the city. (Urbanisation and Emerging Population Issues Working Paper 7. Retrieved from:http://www.unfpa.org/sites/default/files/resourcepdf/UEPI\%207\%20Tacoli\%20Mar\%202012.pdf.

[20] Tacoli, C. \& Satterthwaite, D. (2013). Editorial: Gender and Urban Change. Environment and Urbanisation.Vol.25,38.Retrievedfrom: http://eau.sagepub.com/content/25/1/3.full.pdf+html.

[21] Taylor, A. (2011). Women and the City: Examining the Gender Impact of Violence and Urbanisation. Action Aid. Retrieved from: http://wwwactionaid.org/publications/women-and-city-examininggender-impact-violence-and-urbanisation.

[22] UNFPA \& GTZ (eds) (2007). Social cohesion, Reconciliation Policies and Public Budgeting: A Gender View, UNFPA and German Technical Cooperation, Mexico City

[23] UNFPA \& PRB (2005). Country Profiles for Population and Reproductive Health: Policy Developments and Indicators 2005, UNFPA and Population Reference Bureau, New York and Washington, DC

[24] UN-Habitat (2006). State of the World's Cities 2006/7: The Millennium Development Goals and Urban Sustainability, London, Earthscan

[25] UN-Habitat (2009). Global Report on Human Settlements 2009: Planning Sustainable Cities, p.xxii. UN-Habitat's Global Urban Observatory estimates that in 2010 urban dwellers will make up 50.6 per cent of the world population

[26] UNRISD (2005). Gender Equality: Striving for justice in an unequal world, United Nations Research Institute for Social Development, Geneva 